THE VOLCANIC ROCKS OF THE LAKE DISTRICT:

A GEOLOGICAL GUIDE TO THE CENTRAL FELLS 


\section{Other Macmillan titles of related interest}

D. V. Ager, The Nature of the Stratigraphical Record

J. R. Haynes, Foraminifera

C. S. Hutchison, Economic Deposits and their Tectonic Setting

H. H. Read and Janet Wilson, Introduction to Geology:

Volume 1 Principles

Volume 2 Earth History (Early Stages of Earth History)

Volume 3 Earth History (Late Stages of Earth History) 


\section{The Volcanic Rocks of the Lake District A Geological Guide to the Central Fells}

F. MOSELEY

Reader in Geology,

Department of Geological Sciences,

University of Birmingham 
(c) F. Moseley 1983

All rights reserved. No part of this publication may be reproduced or transmitted, in any form or by any means, without permission.

First published 1983 by THE MACMILLAN PRESS LTD

London and Basingstoke

Companies and representatives

throughout the world

Printed in Great Britain by

Unwin Brothers Limited

The Gresham Press, Old Woking, Surrey

Typeset by RDL Artset, Sutton, Surrey

ISBN 978-0-333-34977-9

ISBN 978-1-349-06729-9 (eBook)

DOI 10.1007/978-1-349-06729-9

The paperback edition of this book is sold subject to the condition that it shall not, by way of trade or otherwise, be lent, resold, hired out or otherwise circulated without the publisher's prior consent in any form of binding or cover other than that in which it is published and without a similar condition including this condition being imposed on the subsequent purchaser. 


\section{Contents}

Preface

1. Introduction 1

2. Comparison between Modern Volcanoes and the Ordovician Volcano of the Lake District

3. Field Identification of Lake District Volcanic Rocks $\quad 12$

4. The Caledonian Orogeny 25

$\begin{array}{lr}\text { 5. Igneous Intrusions } & 29\end{array}$

6. Field Excursion Itineraries $\quad 33$

A. Buttermere to Honister

B. Borrowdale, High Spy and Newlands $\quad 43$

C. St. John's, High Rigg and Bramcrag $\quad 48$

D. Ullswater to Kirkstone Pass

Da. Gowbarrow $\quad 54$

Db. Barton Fell, Ullswater $\quad 55$

Dc. Hallin Fell $\quad 59$

$\begin{array}{ll}\text { Dd. Place Fell } & 64\end{array}$

De. Kirkstone Pass to Fairfield and St. Sunday Crag $\quad 67$

E. Kirkstone Pass to Kidsty Pike $\quad 72$

$\begin{array}{ll}\text { F. Langdale } & 78\end{array}$

Fa. Langdale Pikes $\quad 85$

$\begin{array}{ll}\text { Fb. Pike o'Blisco } & 85\end{array}$

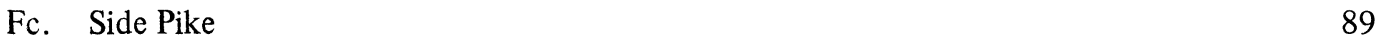

Fd. Crinkle Crags $\quad 90$

G. Coniston $\quad 91$

Ga. South-west Coniston (Timely Knott to Ashgill Quarry) 93

Gb. Long Crag to Church Beck, Coniston $\quad 102$

Gc. Hodge Close, Coniston 104

$\begin{array}{lr}\text { References } & 107\end{array}$

$\begin{array}{ll}\text { Index } & 109\end{array}$ 


\section{Preface}

With few exceptions the Cumbrian mountains are formed from volcanic rocks that are remnants of a volcano active during the Ordovician Period, 450 million years ago. These rocks account for the steep crags of the central fells between Keswick, Coniston, Ambleside and Haweswater. This is the main tourist area of the Lake District to which many thousands of visitors are attracted each year by the magnificent lake and mountain scenery, a scenery that depends to a great extent on the geology. It is understandable therefore that walkers, climbers and even motorists should be curious about the geological origins of the mountains and the valleys, and it is my firm belief that some knowledge of the geology greatly enhances appreciation of the scenery.

This book is an attempt to explain the geology of this beautiful area so that the rocks can be identified and the nature of the ancient volcano understood. It is intended to appeal to those for whom geology is a hobby: to the walker whose curiosity is aroused by the rocky crags and the valleys, to students who have already been introduced to the subject at school and university, and to their teachers who will be experienced geologists, perhaps with considerable knowledge of the Lake District. In order to cater for such a diverse audience I have attempted to explain the geology in simple terms in the early chapters, and then to go into more detail in the excursion itineraries. There are numerous illustrations that should enable the reader to relate distant views of mountainsides to the geology, and to identify the varieties of rocks encountered along the walking routes across the fells.

I wish to acknowledge continuous encouragement from my wife, and the assistance I have received from the Geological Department drawing office at Birmingham University.

Finally I would apologise for my indiscriminate use of miles, kilometres, metres and feet. My excuse is that we should all be bilingual! 